\title{
AKUNTABILITAS PENGELOLAAN ALOKASI DANA DESA MENUJU GOOD GOVERNMENT GOVERNANCE
}

\author{
Pancawati Hardiningsih, Rachmawati Meita Oktaviani, Ceacilia Srimindarti \\ Unisbank Semarang \\ pancawati@edu.unisbank.ac.id
}

\begin{abstract}
ADD revenue in Pemalang sub-district of Pemalang district increased from 2015 and 2016 so that the village government must manage accountable village funds in an accountable manner according to Permendagri No. 113 of 2014. The research was conducted by survey method in 13 villages in the Pemalang sub-district of Pemalang district. A total of 72 village officials consisted of village heads, secretaries, treasurers, activity implementation teams, village consultative bodies, and affairs heads. The results showed that the management of village finances at the planning, implementation, administration, reporting and accountability stages did not fully go well according to Permendagri No. 113 of 2014 and Pemup No. 58 of 2015. The planning stage is still oriented toward physical development. The implementation phase is carried out by the activity implementation team that the development activities are orderly and according to standards. At the administration stage, the village treasurer concurrently holds another position so that he does not fully understand the task. In the reporting stage, the village head reports the realization of the use of the budget to the regent through the related SKPD. In the accountability stage, the village head is responsible for the use of the budget to the local government, village consultative bodies, and the community. The results of the management of the Pemalang district village fund allocation have not yet fully implemented the principles of good government governance in the form of transparency and accountability because many village officials have retired and even moved assignments so what happens is a dual position. But routinely followed up with audits from the inspectorate to maintain the quality of the report.
\end{abstract}

Keywords: Planning, Implementation, Administration, Reporting and Accountability 


\begin{abstract}
ABSTRAK
Jumlah penerimaan ADD di kecamatan Pemalang kabupaten Pemalang meningkat dari tahun 2015 dan 2016, sehingga pemerintah desa harus melakukan pengelolaan dana desa yang dapat dipertanggungjawabkan secara akuntabel sesuai Permendagri Nomor 113 tahun 2014. Penelitian dilakukan dengan metode survey pada 13 desa wilayah kecamatan Pemalang kabupaten Pemalang. Jumlah sampel sebanyak 72 aparat desa terdiri kepala desa, sekretaris, bendahara, tim pelaksana kegiatan, badan musyawarah desa, dan kepala urusan. Hasil penelitian menunjukkan bahwa pengelolaan keuangan desa pada tahap perencanaan, pelaksanaan, penatausahaan, pelaporan, dan pertanggungjawaban belum sepenuhnya berjalan baik sesuai Permendagri Nomor 113 tahun 2014 dan Perbup Pemalang No. 58 Tahun 2015.Tahap perencanaan masih berorientasi pembangunan fisik. Tahap pelaksanaan dilakukan oleh tim pelaksana kegiatan bahwa kegiatan pembangunan tertib dan sesuai standar. Pada tahap penatausahaan bendahara desa merangkap jabatan lain sehingga belum sepenuhnya memahami tugas. Dalam tahap pelaporan kepala desa melaporkan realisasi penggunaan anggaran kepada bupati melalui SKPD terkait. Dalam tahap pertanggungjawaban kepala desa bertanggungjawab atas penggunaan anggaran kepada pemerintah daerah, badan musyawarah desa, dan masyarakat. Hasil pengelolaan alokasi dana desa kabupaten Pemalang belum sepenuhnya mengimplementasikan prinsip good government governanance dalam bentuk transparansi dan akuntabilitas karena banyak aparat desa sudah purna tugas bahkan pindah tugas sehingga yang terjadi adalah rangkap jabatan. Namun secara rutin ditindaklanjuti audit dari inspektorat untuk menjaga kualitas laporan.
\end{abstract}

Kata kunci: Perencanaan, Pelaksanaan, Penatausahaan, Pelaporan dan Pertanggungjawaban 


\section{PENDAHULUAN}

Asas desentralisasi dalam lingkup sempit diterapkan pada sistem pemerintahan desa (pemdes) bahwa pembangunan desa diserahkan sepenuhnya kepada pemdes melalui fasilitas bantuan dana, pembinaan dan pengawasan dari pemerintah pusat. Pemdes dipandang mampu melihat kondisi daerahnya sendiri, baik potensi sumber daya yang dimiliki, sarana dan prasarana yang dibutuhkan serta hal-hal lainnya untuk menyelenggarakan pembangunan desa yang bertujuan memaksimalkan pembangunan desa melalui pontensi desanya.

Adanya Undang-Undang Nomor 6 Tahun 2014 tentang desa, pemerintah mengalokasikan dana desa dalam Anggaran Pendapatan Dan Belanja Negara (APBN) bagi desa melalui transfer Anggaran Pendapatan Dan Belanja Daerah (APBD) kabupaten/kota untuk pembangunan desa, yaitu dalam bentuk Alokasi Dana Desa (ADD). UU tersebut menjelaskan bahwa desa akan mendapatkan kucuran dana sebesar paling sedikit $10 \%$ dari dana perimbangan yang diterima kabupaten/kota dalam Anggaran Pendapatan Dan Belanja Daerah (APBD) setelah dikurangi alokasi dana khusus.

Sehubungan dengan diterimanya ADD maka pemdes harus melakukan pengelolaan keuangan desa berdasarkan asas-asas transparan, akuntabel, partisipatif serta dilakukan dengan tertib dan disiplin anggaran seperti dalam Permendagri Nomor 113 tahun 2014. Hal ini menunjukkan bahwa keuangan desa harus dikelola secara terbuka, dapat dipertanggungjawabkan serta sesuai dengan peraturan yang ada. Penerapan asas-asas tersebut digunakan untuk mengantisipasi terjadinya kecurangan dalam proses pengelolaan keuangan desa. Untuk menyelenggarankan good goverment governance pada pemdes perlu peran masyarakat dalam proses pelaksanaannya, bahwa masyarakat diberi kesempatan terlibat dalam proses perencanaan dan melaksanakan rencana tersebut sesuai dengan asas partisipatif.

Beberapa hasil penelitian yang relevan pada tahap perencanaan oleh Romantis (2015) menunjukkan bahwa perencanaan ADD di 8 desa telah menerapkan prinsip partisipasi dan transparansi. Hal ini dibuktikan dengan kehadiran masyarakat dalam forum musyawarah desa dan pemdes terbuka untuk menerima segala usulan masyarakat yang hadir untuk berjalannya pembangunan di desa terkait. Penelitian serupa oleh Irma (2015) menunjukkan bahwa pengelolaan ADD di wilayah kecamatan Dolo Selatan kabupaten Sigi, pada tahap perencanaan telah terlaksana dengan sangat baik, hal ini dibuktikan adanya musyawarah desa untuk membahas rencana penggunaan ADD. Demikian juga oleh Hanifah dan Suryono (2015) menunjukkan bahwa dalam tahap perencanaan pengelolaan 
ADD di Desa Sidogedungbatu sudah sepenuhnya melaksanakan penerapan azas umum Pengelolaan Keuangan Desa. Hal ini dapat dibuktikan dengan keterlibatan masyarakat desa dalam perencanaan dari penggunaan dana ADD. Hasil serupa oleh Lestari (2017) bahwa tahap perencanaan ADD di 15 desa di kecamatan Banyudono telah menerapkan prinsip partisipasi dan transparansi, yang terbukti dalam kehadiran forum musyawarah desa dan pemdes terbuka untuk menerima segala usulan masyarakat yang hadir untuk berjalannya pembangunan di desa terkait. Wahyudi (2017) menunjukkan bahwa dalam hal pengelolaan ADD di kecamatan Unter Iwes kabupaten Sumbawa pada tahap perencanaan pemdes sudah menjalankan tugasnya dengan baik. Mulai dari penyusunan RPJMDes, RKPDes dan RAPBDes hingga penetapan peraturan desa tentang APBDes.

Pada tahap pelaksanaan oleh Romantis (2015) menunjukkan bahwa pengelolaan ADD di kecamatan Panarukan telah menerapkan prinsip transparansi dan akuntabilitas. Hal ini dibuktikan adanya informasi yang jelas mengenai jadwal pelaksanaan fisik dan pertanggungjawaban secara fisik serta administrasinya sudah selesai dan lengkap. Demikian juga Irma (2015) bahwa tahap pelaksanaan pengelolaan ADD di wilayah kecamatan Dolo Selatan Kabupaten Sigi telah terlaksana dengan sangat baik. Hal ini ditunjukkan bahwa seluruh kegiatan fisik dan non fisik yang dibayai dengan anggaran ADD diinformasikan kepada seluruh masyarakat desa melalui papan pengumuman di kantor desa setempat. Hasil serupa juga oleh Lestari (2017) menunjukkan bahwa pada tahap pelaksanaan pengelolaan ADD di kecamatan Banyudono telah menerapkan prinsip transparansi dan akuntabilitas. Terbukti adanya informasi yang jelas jadwal pelaksanaan fisik dan pertanggungjawaban secara fisik dan didukung administrasi yang lengkap. Penelitian Wahyudi (2017) menemukan bahwa pengelolaan ADD di kecamatan Unter Iwes kabupaten Sumbawa pada tahap pelaksanaan pemdes sudah berjalan dengan sangat baik. Di mulai dari kepala seksi membuat rancangan anggaran biaya hingga pelaporan dan koordinasi kepada sekretaris desa dan kepala desa atas kegiatan yang dilakukan.

Selanjutnya pada tahap pertanggungjawaban oleh Romantis (2015) menunjukkan bahwa ADD baik secara teknis maupun administrasi sudah baik, namun harus tetap diberikan bimbingan dari pemerintah kecamatan. Demikian juga oleh Irma (2015) menunjukkan bahwa di kecamatan Dolo Selatan kabupaten Sigi pada tahap pertanggungjawaban ADD telah terlaksana dengan baik. Pertanggungjawaban ADD dari sisi fisik di semua desa secara umum dapat dikatakan baik, hanya terdapat beberapa desa yang kurang baik, karena sampai saat pengambilan data sarana/prasarana fisik tersebut belum selesai $100 \%$, yang disebabkan dana yang belum mencukupi pada tahun tersebut. 
Tahap penatausahaan penelitian Widiyanti (2017) bahwa dua desa yaitu desa Sumberejo dan desa Kandung di kecamatan Winongan kabupaten Pasuruan menunjukkan bahwa penatausahaan pengelolaan keuangan desa Sumberejo sudah sesuai dengan peraturan undang-undang. Hal ini dibuktikan dari sisi penerimaan, pengeluaran, pencatatan, maupun pertanggungjawaban bendahara telah sesuai dengan Permendagri nomor 113 tahun 2014. Maka desa Sumberejo dalam proses penatausahaan dikatakan accountable. Penelitian di desa Kandung menunjukkan hasil yang sama dalam penatausahaan pengelolaan keuangan desa Sumberejo sudah menggunakan format dengan lampiran dalam Permendagri nomor 113 tahun 2014. Namun dalam pelaksanaan teknis tidak sesuai dengan Permendagri nomor 113 tahun 2014, penatausahaan yang seharusnya dilakukan oleh bendahara desa ternyata tidak dilakukan oleh bendahara melainkan oleh Kepala Desa. Sehingga peneliti menyatakan bahwa penatausahaan Desa Kandung tidak accountable. Demikian juga oleh Wahyudi (2017) menunjukkan bahwa dalam hal pengelolaan ADD di kecamatan Unter Iwes kabupaten Sumbawa pada tahap penatausahaan pemdes sudah berjalan dengan sangat baik, bahwa bendahara desa telah mengerti dan memahami cara pembuatan buku kas umum, buku pembantu pajak dan buku bank, namun masih menggunakan aplikasi sederhana yakni microsoft excel.

Pada tahap pelaporan oleh Hanifah dan Suryono (2015) menunjukkan bahwa pertanggungjawaban pelaksanaan program ADD dan APBDes kepada pemerintah tingkat atasnya dilakukan secara periodik. Hasil serupa juga oleh Wahyudi (2017) menunjukkan bahwa pengelolaan ADD di kecamatan Unter Iwes kabupaten Sumbawa tahap pelaporan pemdes sudah berjalan sangat baik, dimana kepala desa melaporkan realisasi penggunaan anggaran kepada bupati melalui SKPD terkait. Kondisi serupa juga terjadi padakabupaten Pekalongan, bahwa pemdes juga menerima peningkatan jumlah ADD tahun 2015 dan 2016 guna pembangunan desanya. Oleh karena itu tujuan penelitian ini ingin mengetahui bagaimana transparansi dan akuntabilitas pengelolaan ADD melalui tahap perencanaan, pelaksanaan, pertanggungjawaban, penatausahaan, dan pelaporan pada kecamatan Pemalangkabupaten Pemalang. Harapan yang bisa diperoleh dalam penelitian ini dapat mengetahui hambatan dalam pengelolaan keuangan dan solusi bagi pengelola desa untuk meningkatkan transparansi dan akuntabilitas pengelolaan keuangan. 


\section{KAJIAN TEORITIS}

\section{Stewardship theory}

Teori stewardship berasumsi bahwa manusia pada hakikatnya mampu bertindak dengan penuh tanggung jawab, dapat dipercaya, berintegritas tinggi dan memiliki kejujuran. Teori ini memandang steward (pemerintah) sebagai pihak yang mampu melaksanakan tindakan yang sebaik-baiknya ditujukan untuk memenuhi kebutuhan principal (masyarakat). Konsep teori ini berdasarkan asas kepercayaan pada pihak yang diberikan wewenang, dimana manajemen dalam suatu organisasi dicerminkan sebagai good steward yang melaksanakan tugas yang diberikan oleh atasannya dengan penuh tanggung jawab.

Steward tidak memiliki keinginan untuk memenuhi kepentingan pribadi, melainkan lebih mengutamakan pemenuhan kebutuhan principal. Hal ini menghindarkan adanya konflik kepentingan antara steward dengan principal yang menjalankan fungsi eksekutif organisasi. Steward juga akan lebih mementingkan kredibilitas atau kepercayaan publik. Prinsip dasar yang digunakan adalah steward merasa memiliki tanggungjawab yang besar dalam hal pengelolaan dan pengalokasian sumber daya yang ada secara bijaksana dan hati-hati untuk melaksanakan pelayanan kebutuhan masyarakat luas, sehingga mereka tidak termotivasi untuk memenuhi keinginan pribadi, tetapi dengan memenuhi kebutuhan masyarakat luas maka steward merasa bahwa terpenuhinya aktualisasi diri dengan meningkatnya kepercayaan publik.

Peran stewards (pemdes) sebagai suatu lembaga yang dapat dipercaya untuk melaksanakan tugas dan fungsinya dengan baik dan sesuai dengan kepentingan publik, membuat pertanggungjawaban keuangan kepada principalguna terselenggaranya tujuan ekonomi, pelayanan publik maupun kesejahteraan masyarakat dapat tercapai secara maksimal. Untuk melaksanakan tanggungjawab tersebut maka stewards melakukan pengendalian intern untuk dapat menghasilkan laporan informasi keuangan yang berkualitas.

\section{Alokasi Dana Desa}

Alokasi Dana Desa (ADD) adalah dana yang bersumber dari Anggaran Pendapatan dan Belanja Daerah (APBD) kabupaten dengan tujuan pemerataan kemampuan keuangan antar desa untuk mendanai kebutuhan desa dalam rangka penyelenggaraan pemerintahan dan pelaksanaan pembangunan serta pelayanan masyarakat. ADD merupakan perolehan 
bagian keuangan desa dari kabupaten yang penyalurannya melalui kas desa. ADD adalah bagian dana Perimbangan Keuangan Pusat dan Daerah yang diterima oleh kabupaten.

Dalam pengelolaan ADD dibentuk tim kabupaten yang selanjutnya disebut Tim Fasilitasi Kabupaten, tim pendamping yang selanjutnya disebut Tim Pendamping Kecamatan sedangkan di desa disebut Tim Pengelola Desa. Kemudian ada pula Pengawas Kegiatan dan Penanggungjawab Operasional (PJOK).

\section{Akuntabilitas}

Akuntabilitas merupakan salah satu faktor terselenggaranya good government pada pengelolaan pemerintahan. Untuk mencapai good government dalam pemerintahan perlu pertanggungjawaban dalam sistem pengelolaannya melalui laporan keuangan. Prinsip dasar dalam pengelolaan keuangan daerah menurut Mardiasmo dalam Halim, Restianto, dan Karman (2010) menyatakan bahwa perubahan dalam pengelolaan keuangan daerah harus tetap berpegang pada anggaran. Prinsip manajemen keuangan daerah untuk mengontrol kebijakan keuangan daerah tersebut meliputi: (1) Akuntabilitas; (2) Value for money; (3) Kejujuran dalam pengelolaan keuangan publik (probity); (4) Transparansi; dan (5) Pengendalian.

\section{Pengembangan Model}

Kerangka model penelitian ini dapat digambarkan sebagai berikut:

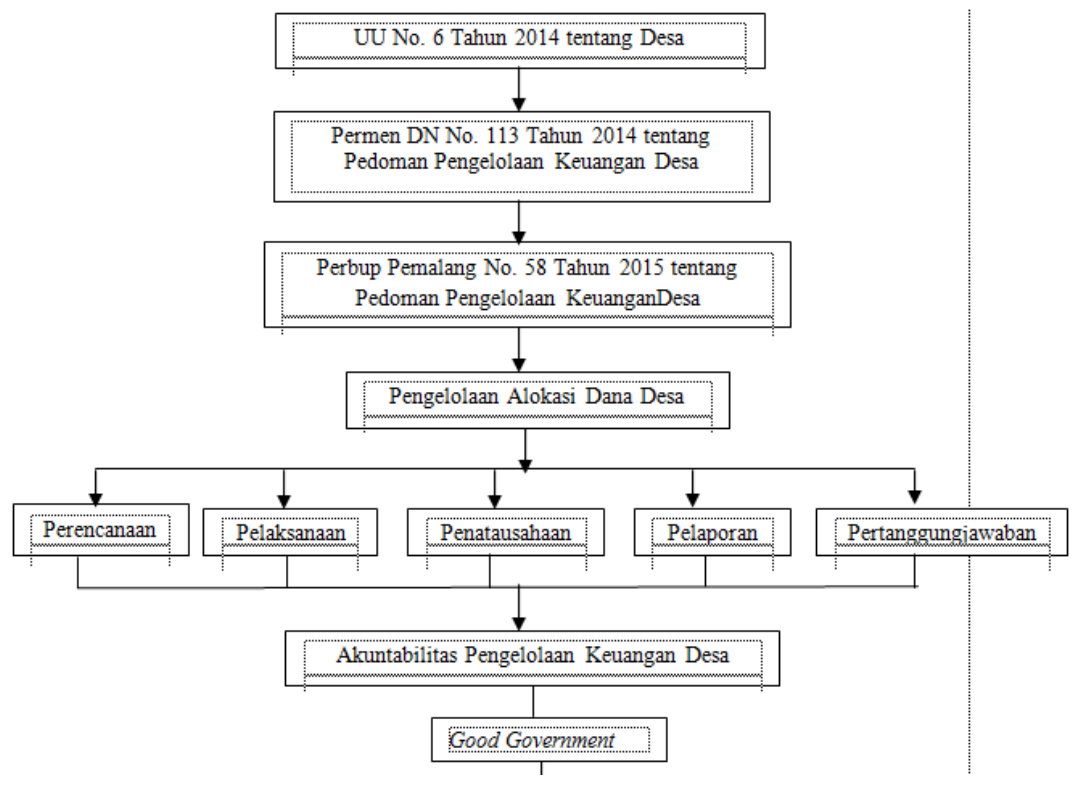

Gambar 1. Model Penelitian 
Accountability merupakan konsep yang lebih luas dari stewardship. Stewardship mengacu pada pengelolaan atas suatu aktivitas secara ekonomis dan efisien tanpa dibebani kewajiban untuk melaporkan, sedangkan accountability mengacu pada pertanggungjawaban oleh steward kepada pemberi tanggungjawab (Mardiasmo:2002).

Dalam tahap perencanaan pemdes menyusun perencanaan pembangunan desa dengan menyelenggarakan musyawarah. Musyawarah dilakukan dengan tujuan untuk menampung aspirasi masyarakat sehingga keputusan yang diambil atas kesepakatan bersama. Tahap perencanaan diwujudkan dengan penyusunan Rancangan Peraturan Desa tentang APBDesa berdasarkan RKPDesa tahun berkenaan yang dilakukan oleh Sekretaris Desa.

Pada tahap pelaksanaan ADD dilakukan oleh Tim Pelaksanan Desa sesuai dengan rancangan yang telah disusun pada tahap perencanaan. Perlu adanya keterbukaan informasi dalam proses ini dengan menyampaikan informasi yang jelas kepada masyarakat mengenai kegiatan fisik ADD melalui papan informasi yang dipasang pada lokasi kegiatan.

Kemudian pada tahap pertanggungjawaban penggunaan ADD dipertanggungjawabkan melalui laporan pertanggungjawaban. Kepala Desa menyampaikan laporan pertanggungjawaban realisasi pelaksanaan APBDes kepada bupati/walikota setiap akhir tahun anggaran.

Tahap penatausahaan bendahara desa membuat dokumentasi surat pertanggungjawaban pengguna dana untuk masing- masing rincian penerimaan dan pengeluaran. Dan mencatat setiap penerimaan dan pengeluaran menggunakan buku kas umum, buku kas pembantu pajak dan buku bank.

Dan tahap pelaporan kepala desa menyampaikan laporan realisasi pelaksanaan APBDes kepada bupati berupa laporan semester pertama dan laporan semester akhir tahun.

Dari kelima tahap diatas steward harus bisa mempertanggungjawabkan penggunaan ADD pada setiap prosesnya, dimana pada dasarnya dalam teori stewardship kepentingan organisasi menjadi tujuan utamanya. Sehingga steward melaksanakan tugas dan fungsinya dengan baik dan sesuai dengan kepentingan publik, membuat pertanggungjawaban keuangan guna terselenggaranya tujuan ekonomi, pelayanan publik maupun kesejahteraan masyarakat dapat tercapai secara maksimal untuk dipertanggungjawabkan kepada principal. 


\section{METODOLOGI}

\section{Jenis Penelitian}

Jenis penelitian ini adalah penelitian kualitatif dengan pendekatan analisisdeskriptif. (Nawawi dan Martini, 1996) yaitu model penelitianyang dilakukan untuk menggambarkan suatu variabel mandiri/ lebih. Tanpa membandingkan atau menghubungkan dengan variabel atau sampel yang lain (Supriyanto,2009:117).Penelitian ini bertujuan untuk menggambarkan bagaimana kemampuan desa- desa dikecamatan Pemalang dalam melaksanakan pengelolaan ADD melalui tahap-tahap pengelolaan dan kesesuaian terhadap peraturan yang berlaku.

\section{Objek Penelitian}

Kabupaten Pemalang merupakan salah satu dari 35 kabupaten/kota yang berada diwilayah Provinsi Jawa Tengah dengan luas wilayah $111.530 \mathrm{~km}^{2}$ dan jumlah penduduk sekitar 1.358 .348 jiwa yang terdiri dari 14 kecamatan, 211 desa, dan 11 kelurahan. Lokasi penelitian ini berada di Kecamatan Pemalang Kabupaten Pemalang memiliki luas wilayah $7.996 \mathrm{~km}^{2}$ dengan jumlah desa sebanyak 13 desa yaitu desa Banjarmulya, Surajaya, Pegongsoran, Sungapan, Kramat, Wanamulya, Mengori, Sewaka, Saradan, Bojongnangka, Tambakrejo, Lawangrejo, dan Danasari.

\section{Jenis dan Sumber Data}

\section{Data Primer}

Penelitian ini membutuhkan jawaban dari aparat desa yaitu melalui kuesioner dan wawancara langsung dengan aparat desa untuk memperoleh data dan informasi yang akurat. Jumlah kuesioner tahap perencanaan berjumlah 14 instrumen, tahap pelaksanaan ada 20 instrumen, tahap penatausahaan ada 9 intrumen, tahap pelaporan ada 7 instrumen, dan tahap pertanggungjawaban sebanyak 13 instrumen.

\section{Data Sekunder}

Sumber data sekunder dari penelitian ini dari catatan dan dokumen perencanaan, pelaksanaan, penatausahaan, pelaporan, dan pertanggungjawaban yang berkaitan dengan pengelolaan ADD. Adapun data tersebut berupai daftarkehadiran peserta rapat musyawarah desa (musdes), berita acara musdes, dokumen Rencana Kerja Pemerintahan Desa (RKPDes), Rancangan Perdes tentang APBDes, Peraturan Desa tentang APBDes, Dokumen Rencana Anggaran Biaya, Surat Permintaan Pembayaran, pernyataan tanggung 
jawab belanja, Bukti Transaksi, buku kas pembantu kegiatan, perdes tentang jenis dan tarif pungutan desa, perdes tentang perubahan APBDesa, Buku kas umum, buku kas pembantu pajak, buku bank, Laporan Semester Pertama, Laporan Semester Akhir Tahun Laporan pertanggungjawaban realisasi pelaksanaan APBDesa, Laporan Kekayaan Milik Desa, dan Laporan tentang Program Pemerintah dan Pemerintah Daerah yang dilaksanakan di Desa.

\section{Populasi dan Sampel}

Populasi dalam penelitian ini adalah seluruh aparat desa yang berada di desa wilayah kecamatan Pemalang. Informan yang terpilih dalam penelitian ini dengan metode nonprobability sampling dan teknik purposive sampling (Sugiyono,2014:122) dengan kriteria aparat desa yang memiliki tugas dan wewenang dalam pengelolaan ADD. Informan yang menjadi sampel adalah kepala desa, sekretaris desa, tim pelaksana kegiatan, kepala seksi, bendahara desa, dan badan musyawarah desa sebanyak 72 .

\section{Teknik Analisis Data}

Penelitian ini menggunakan deskriptif kualitatif yaitu pengolahan/analisis data dilakukan dengan cara mendeskripsikan unsur-unsur yang merupakan bagian dari setiap tahap, atau sebaliknya mengkombinasikan dan mengintegrasikan semua tahap yang terpisah-pisah, sehingga menjadi satu kesatuan yang utuh.

\section{PEMBAHASAN}

\section{Deskripsi Responden}

Karakteristik responden berdasarkan tingkat pendidikan, dan lama jabatan dapat digambarkan sebagai berikut:

Tabel 1

Karakteristik Responden Berdasarkan Tingkat Pendidikan

\begin{tabular}{|c|c|c|c|}
\hline No. & Tingkat & Orang & Persentase \\
\hline 1 & SMA & 5 & $69 \%$ \\
\hline 2 & DIPLOMA & 9 & 13 \\
\hline 3 & SarjanaS-1 & 1 & $18 \%$ \\
\hline \multicolumn{2}{|c|}{ Jumlah } & 7 & $100 \%$ \\
\hline
\end{tabular}

Sumber: data diolah, 2018 
Tabel 2

Karakteristik Responden Berdasarkan Lama Bekerja

\begin{tabular}{|c|l|c|r|}
\hline No. & Frekuensi & Orang & Persentase \\
\hline 1 & $<5$ Tahun & 3 & $43 \%$ \\
\hline 2 & $5-10$ Tahun & 1 & $19 \%$ \\
\hline 3 & $>10$ Tahun & 2 & $38 \%$ \\
\hline \multicolumn{2}{|c|}{ Jumlah } & 7 & $100 \%$ \\
\hline
\end{tabular}

Sumber: data diolah, 2018

Pada tabel 1 terlihat tingkat pendidikan, aparat desa diwilayah kecamatan Pemalang memiliki tingkat pendidikan yang memadai sesuai dengan UU No.6 tahun 2014 tentang desa pasal 3 menyatakan bahwa seorang calon kepala desa berpendidikan paling rendah tamatan sekolah menengah pertama atau sederajat dan Peraturan Daerah Pemalang tahun 2010 tentang pengangkatan dan pemberhentian perangkat desa pasal 4 dan 5 yang menyatakan bahwa seorang sekretaris desa berpendidikan paling rendah adalah lulusa nsekolah lanjutan tingkat atas atau sederajat sedangkan perangkat desa lain berpendidikan paling rendah lulusan sekolah lanjutan tingkat pertama atau sederajat. Latar belakang pendidikan aparatur desa adalah SMA, Diploma dan Sarjana S-1 namun masih perlu pendampingan dan pembinaan dalam hal pengelolaan keuangan desa.

Tabel 2 menunjukkan bahwa terdapat aparatur desa yang masih tergolong baru dalam bekerja, dimana aparatur desa ini masih membutuhkan pembinaan dan pendampingan. Diharapkan pemda maupun instansi terkait dapat memberikan pembinaan dan pendampingan terhadap aparatur desa yang tergolong baru tersebut, agar tugas aparatur desa tersebut dapat berjalan dengan baik.

\section{Tahap Perencanaan}

Hasil distribusi frekuensi jawaban kuesioner responden pada tahap perencanaan terlihat pada tabel 5 sebagai berikut:

\section{Tabel 5}

Frequensi Tabel Tahap Perencanaan

\begin{tabular}{|c|c|c|c|c|c|c|c|c|c|c|c|c|c|c|c|c|}
\hline \multicolumn{14}{|c|}{ Frekuensi } & Jumlah & SkorSkala & TotalSkor \\
\hline 1 & 2 & 3 & 4 & 5 & 6 & 7 & 8 & 9 & 10 & 11 & 12 & 13 & 14 & & & \\
\hline- & - & - & - & - & - & - & - & - & - & - & - & - & - & - & 1 & - \\
\hline- & 3 & - & - & 6 & - & - & 4 & - & 3 & 3 & 5 & 1 & 1 & 26 & 2 & 52 \\
\hline 43 & 45 & 52 & 45 & 46 & 48 & 55 & 51 & 52 & 53 & 46 & 48 & 54 & 42 & 680 & 3 & 2.040 \\
\hline 29 & 24 & 20 & 27 & 20 & 24 & 17 & 17 & 20 & 16 & 23 & 19 & 17 & 29 & 302 & 4 & 1.208 \\
\hline \multicolumn{16}{|c|}{ Total } & 3.300 \\
\hline \multicolumn{16}{|c|}{ keputusan } & Baik \\
\hline
\end{tabular}

Sumber: Data diolah 2018 
Tabel 5 menunjukkan bahwa hasil kuesioner tahap perencanaan desa wilayah kecamatan Pemalang sudah berjalan dengan baik artinya perencanaan sesuai dengan aturan yang berlaku. Kondisi ini didukung dengan hasil wawancara bahwa aparat desa dalam tahap perencanaan sudah berjalan baik mulai dilakukan musyawarah dusun (musdus) pada tingkat dusun yang melibatkan semua elemen masyarakat serta lembaga di masyarakat desa seperti tokoh agama, tokoh pemuda, ibu-ibu PKK untuk menampung aspirasi dan saran dari pemdes dan Badan Permusyawaratan Desa (BPD) untuk membuat RPJM. Kaur pembangunan mencatat beberapa usulan dari masing-masing dusun, untuk selanjutnya melakukan musyawarah desa (musdes). Dari musdes tersebut terbentuk Tim Pelaksana Kegiatan (TPK) dan Panitia Pelaksana Kegiatan (PPK). Setelah RPJM tersusun maka akan menghasilkan RKPDes. Selanjutnya RAPBDes disepakati bersama oleh kepala desa dan BPD kemudian dievaluasi oleh bupati melalui camat hingga penetapan APBDesa. APBDes berisi kegiatan pembangunan dalam kurun satu tahun yang harus dilaksanakan berdasarkan skala prioritas.

Hasil tersebut didukung dokumentasi yang menunjukkan keadaan yang baik bahwa semua desa dapat menunjukkan dokumen dan sesuai dengan peraturan yang berlaku. Temuan ini juga didukung dengan hasil wawancara yang menyatakan bahwa:

"Tahapan perencanaan melakukan musyawarah seperti Musyawarah Rencana Kerja Pembangunan Desa (RKPDes) melalui musdus kemudian dilanjutkan ke musdes. Musyawarah melibatkan semua elemen masyarakat seperti lembaga masyarakat desa, tokoh masyarakat desa, tokoh agama, tokoh pemuda maupun ibu-ibu PKK untuk penggalian gagasan. Setelah RKPDes selesai maka dituangkan kembali ke dalam RAPBDesa". (Singgih Suswinarso, Sekretaris BPDDesa Lawangrejo, Rabu 4 April 2018, 10.30Wib).

Kepala desa menyelenggarakan musdus yang diikuti oleh pemdes, BPD, dan unsur masyarakat yang terdiri atas: tokoh adat, tokoh agama, tokoh masyarakat, tokoh pendidikan, serta unsur masyarakat lain sesuai kondisi sosial budaya masyarakat untuk membahas dan menyepakati rancang RPJMDes dan RKPDesa. Hasil kesepakatan musdes dituangkan dalam berita acara. Hal ini didukung oleh hasil wawancara dan hasil dokumentasi bahwa:

"Penyusunan rancangan RAPBDesa kami selalu melibatkan beberapa tokoh masyarakat seperti tokoh pendidikan, tokoh kesehatan yang kami harapkan bisa mengisi yang sifatnya pelayanan mendasar misalnya dunia pendidikan, dunia kesehatan itu merupakan pelayanan dasar terkait penganggaran kedepannya. 
Jadi usulan-usulan itu ditampung melalui kegiatan musdes”. (Imam Sukamto, Kepala Desa Surajaya, Kamis 2 April2018, 14.30 Wib)

"Kami selalu melibatkan masyarakat dalam proses perencanaan APBDesa. Kami mengundang semua perangkat desa, penggerak PKK, ketua $R T$, ketua $R W$, Kadus, tokoh agama”. (Mulyono, Kepala Desa Uma Beringin, Jumat 3 April2017, 10.17Wib)

Namun aspirasi masyarakat masih berfokus pada pembangun fisik seperti untuk membangun / merehap balai desa karena rusak atau bahkan penambahan ruang, pagar balai desa, pendopo, gedung sekretariat, drainase, pengaspalan dll. Padahal penggunaan keuangan desa juga dapat digunakan untuk pembiayaan penyelenggaraan pemerintah desa, pelaksanaan pembangunan desa, pembinaan kemasyarakatan desa, dan pemberdayaan masyarakat desa. Hal ini ditunjukkan hasil wawancara yang menyatakan bahwa:

"Pada musdus, kebanyakan usulan warga masih prioritas ke fisik, seperti pembangunan balai desa, pembangunan jalan, saluran drainase. Karena saat ini memang butuh perbaikan. Sedangkan untuk pemberdayaan dan pembinaan masyarakat masih belum diprioritaskan".(Cipto Hendianto, Sekeretaris Desa Mengori, Kamis 12 April, 9.13Wib)

Pernyataan dari responden diperkuat dengan bukti lapangan dimana hasil dari musdes di Desa Lawangrejo, desa Barjarmulyo, desa Kramat, desa Surajaya dll hanya berfokus ke pembangunan desa. Namun desa Sungapan selama tahu 2015/2016 tidak ada pembangunan fisik tetapi dana digunakan untuk pembinaan kemasyarakatan desa, dan pemberdayaan masyarakat desa. Selanjutnya hasilmusdes tersebut akan menjadi acuan pemdes dalam penyusunan RAPBDes. Kemudian RAPBDesa tersebut disampaikan oleh sekretaris desa kepada kepala desa. Kemudian kepala desa bersama BPD membahas dan menyepakati Rancangan Peraturan Desa tentang APBDes. Rancangan peraturan desa tentang APBDesa yang telah dibahas dan disepakati bersama oleh BPD dan kepala desa selanjutnya dibuatkan berita acara. Peraturan desa tentang APBDesa harus selaras dengan Rencana Kerja Pembangunan Desa (RKPDes). Untuk selanjutnya kepala desa menyampaikan kepada bupati melalui camat untuk dievaluasi. Evaluasi desa-desa diwilayah Kecamatan Pemalang tidak mengalami kendala yang berarti dan berjalan baik. Hal ini sesuai dengan jawaban hasil wawancara yaitu:

"Rancangan perdes tentang APBDesa yang disampaikan kepada bupati melalui camat untuk dievaluasi lebih lanjut berjalan dengan baik dan tidak ada masalah 
yang kami temui."(Saman, Kepala Desa Danasari, Jumat April 2018, 10.18 Wib)

Setelah RAPBDes selesai dievaluasi bupati dan telah disempurnakan oleh kepala desa, maka kepala desa mengeluarkan peraturan desa tentang APBDes agar anggaran dapat segera ditransfer ke rekening kas desa dan dapat dengan segera digunakan. Dari uraian di atas dapat disimpulkan bahwa penyusunan RAPBDes hingga menjadi APBDes, desa-desa diwilayah kecamatan Pemalang menjalankan tugasnya dengan baik berdasarkan aturan yang berlaku serta didukung dengan hasil wawancara aparatur desa dan dilengkapi dokumen.

\section{Tahap Pelaksanaan}

\begin{tabular}{|c|c|c|c|c|c|c|c|c|c|c|c|c|c|c|c|c|c|c|c|c|c|c|}
\hline \multicolumn{20}{|c|}{ Frekuensi } & Jumlah & Skor Skala & Total Skor \\
\hline 1 & 2 & 3 & 4 & 5 & 6 & 7 & 8 & 9 & 10 & 11 & \begin{tabular}{|l|}
12 \\
\end{tabular} & 13 & 14 & \begin{tabular}{|l|}
15 \\
\end{tabular} & 16 & 17 & 18 & 19 & 20 & & & \\
\hline- & - & - & - & - & - & - & - & - & - & - & - & - & - & - & - & - & - & & & _ & 1 & - \\
\hline- & 1 & 1 & 2 & 2 & 7 & - & - & - & 1 & - & \begin{tabular}{|l|}
10 \\
\end{tabular} & 1 & - & 1 & - & - & - & - & 10 & 36 & 2 & 72 \\
\hline 41 & 39 & 39 & 41 & 46 & 46 & 49 & 45 & 41 & 44 & 42 & 46 & 45 & 38 & 43 & 40 & 49 & 44 & 42 & 46 & 866 & 3 & 2.59 \\
\hline 31 & 32 & 32 & 29 & 24 & 19 & 23 & 27 & 31 & 27 & 30 & 16 & 26 & 34 & 28 & 32 & 23 & 28 & 30 & 16 & 538 & 4 & 4.82 \\
\hline \multicolumn{23}{|c|}{$\mathrm{J}$} \\
\hline & & & & & & & & & & & Ket & era & ngal & & & & & & & & & ik \\
\hline
\end{tabular}

TPK telah menjalankan tugasnya dengan baik sesuai aturan pengelolaan ADD. Hasil ini didukung wawancara bahwa hampir seluruh desa pada tahap pelaksanaan sudah berjalan baik dan didukung dokumen. Namun penunjukan dokumen tidak sepenuhnya dapat ditunjukkan kepada peneliti oleh pemdes karena sifat rahasia.

Dalam pelaksanaan anggaran desa semua penerimaan dan pengeluaran desa dilaksanakan malalui rekening kas desa dan didukung oleh bukti yang lengkap dan sah. Pejabat Teknis Pengelola Keuangan Desa (PTPKD) sudah menjalankan tugasnya dengan baik, hal ini dibuktikan dengan PTPKD telah membuat Rancangan Anggaran Biaya (RAB) yang sudah diverifikasi oleh sekretaris desa dan disahkan oleh kepala desa. TPK dan PPK menggunakan buku pembantu kas kegiatan sebagai pertanggungjawaban pelaksana kegiatan, TPK mengajukan Surat Permintaan Pembayaran (SPP), membuat pernyataan pertanggungjawaban belanja, dan melampirkan bukti transaksi. Hal ini didukung oleh hasil wawancara yang menyatakan bahwa:

"Dalam hal pelaksanaan kegiatan kami membuat RAB atas beban pengeluaran kegiatan."(Sriyanti, TPK Desa Kramat, Senin 2 April 2018,11.05 Wib)

"TPK membuat RAB dan SPP yang kemudian diverifikasi oleh sekdes dan diketahui oleh kades baru saya bisa mengeluarkan uang. "(Hasan, Bendahara Desa Pegongsoran Selasa3April201, 9.13Wib) 
"Pelaksana kegiatanya itu Tim Pelaksana Kegiatan (TPK) dan Panitia Pelaksana Kegiatan (PPK). TPK juga melakukan pembukuan. TPK membuat buku kas pembantu kegiatan, surat pernyataan tanggungjawab. Sekarang itu pelaksana kegiatan memegang kegiatan dan meminta uang ke bendahara dan kemudian dibukukan dan dibelanjakan oleh pelaksana kegiatan itu'.(Satyawati, Sekretaris Desa Kramat, Senin 2 April2018, 10.53Wib)

Pelaksana kegiatan adalah TPK dan PPK bertanggung jawab terhadap kegiatan yang dilakukan dan selalu berkoordinasi serta melaporkan kepada sekdes dan kades tentang kegiatan yang dilakukan. Hal ini diperkuat dengan hasil wawancara bahwa:

"kami tetap melaporkannya, bila ada kekurangan dana, kami selalu berkoordinasi kepada sekdes dan kades. TPK juga bertanggungjawab atas kegiatan tersebut, karena TPK langsung yang mengelola dana" (Sriyanti, TPK Desa Kramat, Senin 2 April 2018,11.05Wib)

Beberapa kendala dalam pelaksanaannya yaitu kurangnya kemampuan sumberdaya manusia dalam menggunakan teknologi yang telah tersedia sehingga membuat aparat desa kurang memahami teknologi dalam menyelesaikan pekerjaan. Hal ini dikemukakan oleh aparatur desa bahwa:

"Saya belum fasih memahami teknologi komputer. Jadi dalam pembuatan RAB, saya membuatnya secara manual tulis tangan baru diketik".(Hidayat, TPK Desa Pegongsoran, Selasa3 April 2018, 10.35Wib)

"Terdapat kendala SDM yang berumur tua dan lambatnya dalam memahami teknologi komputer”. (Singgih Suswinarso, Sekeretaris Desa Lawangrejo, Kamis 5April, 9.13Wib)

Kendala lain yang dihadapi dalam membuat buku kas pembantu kegiatan seperti pernyataan aparatur desa bahwa:

"Karena dana desa baru berjalan dua tahun kami belum bisa memaksimal kandala pengelolaannya. Seperti PTPKD sebagian belum paham mengenai cara membuat buku kas pembantu kegiatan karena kebanyakan aparat desa merangkap tugas”.(Hasan, Bendahara Desa Pegongsoran Selasa3April201, 9.13Wib)

Dalam tahap ini juga mengatur pungutan desa sesuai dengan peraturan desa seperti hasil wawancara bahwa:

"dalam peraturan desa ada urusan yang bisa kami pungut dan yang tidak bisa kami pungut. Misalnya pembuatan KK, KTP dan akta kelahiran dll tidak 
dipungut biaya, sedangkan pembuatan surat keterangan ternak dipungut biaya”.(Waskito, Kepala Desa Kramat, Jumat 6 Aprili 2018,14.18 Wib)

Dari uraian diatas dapat disimpulkan bahwa tahap pelaksanaan mulai dari penyusunan RAB hinggga kegiatan selesai dilaksanakan aparat desa wilayah kecamatan Pemalang sudah berjalan dengan baik sesuai aturan yang berlaku serta didukung hasil wawancara aparatur desa dan dilengkapi sebagian besar dokumen.

\section{Tahap Penatausahaan}

\begin{tabular}{|c|c|c|c|c|c|c|c|c|c|c|c|}
\hline \multicolumn{9}{|c|}{ Frekuensi } & \multirow{2}{*}{$\begin{array}{c}\text { Jumlah } \\
\text { Frekuensi }\end{array}$} & \multirow{2}{*}{ SkorSkala } & \multirow[b]{2}{*}{ TotalSkor } \\
\hline 1 & 2 & 3 & 4 & 5 & 6 & 7 & 8 & 9 & & & \\
\hline- & - & - & - & - & - & - & - & - & - & 1 & - \\
\hline 5 & - & - & 2 & - & - & - & - & - & 7 & 2 & 14 \\
\hline 49 & 35 & 34 & 49 & 41 & 38 & 41 & 35 & 34 & 356 & 3 & 1.068 \\
\hline 18 & 37 & 38 & 21 & 31 & 34 & 31 & 37 & 38 & 285 & 4 & 1.140 \\
\hline \multicolumn{11}{|c|}{ Total } & 2.222 \\
\hline \multicolumn{11}{|c|}{ Keputusan } & Baik \\
\hline
\end{tabular}

Hasil kuesioner menunjukkan bahwa tahap penatausahaan di wilayah kecamatan Pemalang sudah berjalan dengan baik. Meskipun demikian bendahara desa berusaha memahami cara pembuatan buku kas umum, buku kas pembantu pajak, dan buku bank. Bendahara desa juga memeriksa bukti pengeluaran dan bukti penerimaan kas secara rutin serta memahami penggunaannya. Hal ini sesuai dengan hasil wawancara bahwa:

"Untuk melakukan pencairan dana harus ada SPP dulu yang diajukan oleh PTPKD baru uangnya dapat dicairkan”. (Aniek Pinatri, Bendahara Desa Mengori, Senin 9April 2018,9.44 Wib)

"Bendahara desa biasanya menerima, menyimpan, membayar, menatausahakan, dan mempertanggungjawabkan uang yang ada" (Dwi Utami, Bendahara Desa Danasari,Selasa10 April2018, 9.13 Wib)

Bendahara desa juga selalu melaporkan kepada kepala desa setiap bulan serta melakukan pengarsipan dengan baik. Namun terdapat beberapa kendala dalam penyusunan buku terkait penatausahaan, seperti disampaikan oleh Sekretaris Desa Lawangrejo yang menyatakan:

"Bila ada hambatan dalam proses penatausahaan oleh bendahara, kami tetap konsultasi ke kabupaten dan memperbaikinya seperti catatanbukukasumum, bukukaspembantu pajak dan penyesuaian dengan RABnya. Karena ini adalah proses pembelajaran baru”(Singgih Suswinarso Sekeretaris Desa Lawangrejo, Kamis 5Aril,10.13Wib) 
Dapat disimpulkan bahwa penatausahaan oleh bendahara desa sudah berjalan dengan baik berdasarkan aturan yang berlaku serta didukung wawancara terhadap aparat desa. Hal ini juga terlihat bahwa bendahara desa selalu mencatat penerimaan dan pengeluaran desa melalui buku kas umum, buku kas pembantu pajak, dan buku bank serta menyampaikannya kepada kepala desa setiap bulan. Namun dalam hal penunjukkan dokumen tidak diperkenankan karena sifat rahasia dan hanya pihak inspektorat yang diperbolehkan.

Tahap Pelaporan

\begin{tabular}{|c|c|c|c|c|c|c|c|c|c|}
\hline \multicolumn{7}{|c|}{ Frekuensi } & \multirow{2}{*}{$\begin{array}{l}\text { Jumlah } \\
\text { Frekuensi }\end{array}$} & \multirow{2}{*}{ Skor Skala } & \multirow[t]{2}{*}{ Total Skor } \\
\hline $\mathbf{1}$ & 2 & 3 & 4 & 5 & 6 & 7 & & & \\
\hline- & - & - & - & - & - & - & - & 1 & \\
\hline- & 1 & 1 & - & 1 & 1 & - & 4 & 2 & 8 \\
\hline 42 & 45 & 48 & 42 & 45 & 48 & 51 & 321 & 3 & 963 \\
\hline 30 & 26 & 23 & 30 & 26 & 23 & 21 & 179 & 4 & 716 \\
\hline \multicolumn{9}{|c|}{ Total } & 1.687 \\
\hline \multicolumn{9}{|c|}{ Keputusan } & Baik \\
\hline
\end{tabular}

Hasil penelitian menunjukkan bahwa kepala desa selalu melaporkan realisasi pelaksanaan APBDes kepada bupati yaitu laporan semester pertama dan laporan semester akhir tahun. Hal ini dipertegas hasil wawancara yang menyatakan:

"Kami selalu membuat dan melaporkan laporan semester pertama dan semester akhir tahun kepada bupati” (Hardoyo, Kepala Desa Mengori,senin 9April 201, 10.13 Wib)

Laporan yang dibuat oleh sekretaris desa kemudian dilaporkan oleh kepala desa kepada bupati. Hal ini dikemukan dalam wawancara kepada aparat desa bahwa:

"Proses pembuatan laporan realisasi penggunaan anggaran dimulai dari laporan TPK dan PPK, kemudian ke bendahara desa, dan kemudian dituangkan oleh sekdes. Karena sekdes adalah kordinator pengelola keuangan" (Singgih Suswinarso Sekeretaris Desa Lawangrejo, Kamis 5 April,10.13 Wib)

Dalam hal pelaporan kepala desa kepada bupati tidak ada kendala artinya berjalan dengan baik. Hal ini dituturkan dalam hasil wawancara yang menyatakan bahwa:

"Tidak ada hambatan sama sekali dalam pelaporan yang saya lakukan". (Fitriyadi, Kepala Desa Tambakrejo, Rabu 4April 2018, 10.01Wib)

Kesimpulan padatahap pelaporan sudah berjalan baik. Dimana kepala desa sebagai penanggung jawab penggunaan dana telah melaporkan realisasi pelaksanaan anggaran dengan baik sesuai aturan yang berlaku. 
Tahap Pertanggungjawaban

\begin{tabular}{|c|c|c|c|c|c|c|c|c|c|c|c|c|c|c|c|}
\hline & \multicolumn{12}{|c|}{ Frekuensi } & \multirow{2}{*}{$\begin{array}{c}\text { Jumlah } \\
\text { Frekuensi }\end{array}$} & \multirow[t]{2}{*}{ SkorSkala } & \multirow[t]{2}{*}{ Total Skor } \\
\hline 1 & 2 & 3 & 4 & 5 & 6 & 7 & 8 & 9 & 10 & 11 & 12 & 13 & & & \\
\hline- & - & - & - & - & - & - & - & - & - & - & - & - & - & 1 & - \\
\hline- & 1 & - & - & 1 & - & 2 & 1 & - & 4 & - & - & 2 & 11 & 2 & \\
\hline 26 & 51 & 47 & 44 & 42 & 44 & 44 & 48 & 51 & 50 & 37 & 44 & 44 & 572 & 3 & 1.716 \\
\hline 46 & 20 & 25 & 28 & 29 & 28 & 26 & 23 & 21 & 18 & 35 & 28 & 26 & 353 & 4 & 1.41 \\
\hline \multicolumn{13}{|c|}{ Total } & & & 3.150 \\
\hline & & & & & & & & & & & & & Keputusan & & Baik \\
\hline
\end{tabular}

Hasil kuesioner menunjukkan bahwa tahap pertanggungjawaban pengelolaan keuangan desa kecamatan Pemalang sudah berjalan baik. Semua laporan tersebut dilaporkan kepada bupati dan akan dilakukan pemeriksaan oleh inspektorat. Seperti yang dikemukakan oleh bendahara desa Surajaya bahwa:

"Bentuk pertanggungjawaban yang saya lakukan adalah setelah semua pelaksanaan kegiatan selesai dilakukan lalu dibuat pembentukan Surat Pertanggungjawaban (SPJ) kemudian d kirim ke instansi-instansi terkaitdan dilakukan jugapemeriksaan yang dilakukan oleh inspektorat. Saat pemeriksaan inspektorat kami biasanya dipanggil ke kantor kecamatan". (Tri Bekti, Bendahara Desa Surajaya, Senin 27 Maret 2018, 9.13Wib)

Bentuk pertanggungjawaban yang dilakukan kepada desa kecamatan Pemalang tidak hanya kepada tingkat pemerintah yang berada di atasnya, namun pelaporan juga ditujukan kepada BPD dan masyarakat. Untuk menjaga transparansi anggaran yang dilakukan pemdes selaku pengelola dana maka pemdes menyampaikan laporan pertanggungjawaban kepada masyarakat melalui forum dan membagi laporan tersebut secara tertulis serta info grafis dalam bentuk MMT tentang penggunaan ADD seperti, seperti yang dikemukakan oleh responden yakni:

"Kami selalu memberikan pertanggungjawaban kepada masyarakat, kami juga mengundang BPD, perwakilan masyarakat,tokoh agama, tokoh pendidikan, tokoh kesehatan sebelum kami memberikan laporan pertanggungjawaban kepada masyarakatdan bahkan membuat MMT dipasang di kantor desa agar masyarakat tahu”.(Sukirman,Kepala Desa Tambakrejo, Kamis 9 April 2018, $10.13 \mathrm{Wib}$ )

Dengan demikian dapat disimpulkan padatahap pertanggungjawaban sudah berjalan dengan baik. Jika SPKPD telah disahkan oleh Presiden menjadi Peraturan Pemerintah maka SPKPD harus segera diterapkan oleh pemerintah desa. Hal ini dimaksudkan untuk mewujudkan transparansi dan akuntabilitas pengelolaan keuangan desa,yang jumlahnya terus meningkat dari tahun ketahun (http://www.kemenkeu.go.id). 


\section{KESIMPULAN}

a. Dalam tahap perencanaan pemdes sudah menjalankan tugasnya dengan baik. Mulai dari penyusunan RPJMDes, RKPDes dan RAPBDes hingga penetapan peraturan desa tentang APBDes. Begitu juga dengan hasil wawancara yang telah menunjukkan hasil yang baik dimana dalam penyusunan RPJMDes, RKPDes dan RAPBDes selalu melibatkan pemerintah desa, BPD, dan masyarakat.

b. Dalam tahap pelaksanaan pemdes sudah berjalan baik. Mulai dari TPK membuat rancangan anggaran biaya hingga pelaporan dan koordinasi kepada sekretaris desa dan kepala desa atas kegiatan yang dilakukannya..

c. Dalam tahap penatausahaan pemdes belum sepenuhnya berjalan baik. Dimana bendahara desa belum sepenuhnya mengerti dan memahami cara pembuatan buku kas umum, buku pembantu pajak dan buku bank dikarenakan kurangnya jumlah aparat desa.

d. Dalam tahap pelaporan pemdes sudah berjalan baik. Dimana kepala desa melaporkan realisasi penggunaan anggaran kepada bupati melalui SKPD terkait.

e. Dalam tahap pertanggungjawaban pemdes sudah berjalan baik. Selaras dengan hasil kuesioner dan wawancara juga menunjukkan bahwa pengelolaan ADD tahap pertanggungjawaban sudah berjalan baik. Dimana kepala desa bertanggungjawab atas penggunaan anggaran kepada pemda, BPD, dan masyarakat.

\section{DAFTAR PUSTAKA}

Amin, Zainul Ittihad. 2013. Pendidikan kewarganegaraan. Tangerang Selatan: Universitas Terbuka.

Astuty, Elgia dan Eva Hany Fanida. 2012. Akuntabilitas Pemerintah Desa dalam Pengelolaan Anggaran Pendapatan dan Belanja Desa (APBDES) (Studi pada Alokasi Dana Desa Tahun Anggaran 2011 di Desa Sareng Kecamatan Geger Kabupaten Madiun). Jurnal Ilmu dan Riset Akuntansi. Universitas Negeri Surabaya.

Ayu A., Chandra. 2016. Analisis Pengelolaan Keuangan Desa Sebagai Bentuk Implementasi Undang-Undang Nomor 6 Tahun 2014. Skripsi. Fakultas Ekonomi dan Bisnis Universitas Mataram.

Faridah dan Bambang Suryono. 2015. Transparansi dan Akuntabilitas Pemerintah Desa Dalam Pengelolaan Anggaran Pendapatan dan Belanja Desa (APBDes). Jurnal Ilmu dan Riset Akuntansi Vol. 4. No.5. Sekolah Tinggi Ilmu Ekonomi Indonesia (STIESIA) Surabaya. 
Halim, Abdul dkk. 2010. Sistem Akuntansi Sektor Publik. Yogyakarta: Unit Penerbit dan Percetakan Sekolah Tinggi Ilmu Manajemen YKPN.

Hanifah, Suci Indah dan Praptoyo, Sugeng. 2015. Akuntabilitas dan Transparansi

Pertanggungjawaban Anggaran Pendapatan Belanja Desa (APBDes). Jurnal Ilmu dan Riset Akuntansi. Surabaya: Sekolah Tinggi Ilmu Ekonomi Indonesia (STIESIA) Surabaya.

https://www.jogloabang.com/pustaka/permendagri-113-tahun-2014-pengelolaankeuangan-desa.

http://www.kuttabku.com/2017/05/pengertian-keterbukaan-prinsip-prinsip-dan-contohserta-ciri-ciri-pemerintah-yang-terbuka-atau-good-governance.html

http://www.ryobinhood.blogspot.co.id.html.

Huri, Risti Valentina. 2015. Akuntabilitas Pengelolaan dan Pemanfaatan AlokasiDana Desa Dalam Proses Pembangunan di Desa Dasri Kecamatan Tegalsari Kabupaten Banyuwangi Tahun 2013. Skripsi. Jember: Universitas Jember.

Irma, Ade. 2015. Akuntabilitas Pengelolaan Alokasi Dana Desa (ADD) di Kecamatan Dolo Selatan Kabupaten Sigi. E-Jurnal Katalogis, Volume 3 Nomor 1, hal 121-137. Universitas Tadulako. Koentjaraningrat. 1993. Metode-Metode Penelitian Masyarakat. Jakarta: PT Gramedia Pustaka Utama.

Lembaga Administrasi Negara dan Badan Pengawasan Keuangan dan Pembangunan RI. 2007. Akuntabilitas dan Good Governance, Modul 1-5, Modul Sosialisasi Sistem Akuntabilitas Kinerja InstansiPemerintah (AKIP), LAN BPKP RI. Jakarta.

Lestari, Sri. 2017. Analisis Akuntabilitas Pengelolaan Alokasi Dana Desa (ADD) (Studi Kasus di Wilayah Kecamatan Banyudono). Skripsi. Surakarta: Institut Agama Islam Negeri Surakarta.

Mardiasmo. 2002. Akuntansi Sektor Publik. Yogyakarta: Andi Offset.

Nafidah, Lina Nasihat un dan Mawar Suryaning tyas. 2015. Akuntabilitas Pengelolaan Alokasi Dana Desa dalam Upaya Meningkatkatan Pembangunan dan Pemberdayaan Masyarakat. Jurnal Bisnis dan Manajemen Islam Vol.3 No. 1. STIE PGRI Dewantara Jombang.

Nawawi, Hadari dan Martini, Mimi. 1996. Penelitian Terapan. Yogyakarta:Gadjah Mada University Press.

Peraturan Menteri Dalam Negeri Republik Indonesia Nomor 113 Tahun 2014tentang Pedoman Pengelolaan Keuangan Desa.

Peraturan Bupati Pemalang Nomor 58 Tahun 2015 Tentang Pedoman Pelaksanaan Alokasi Dana Desa 
Riskasari. 2016. Akuntabilitas Pengelolaan Alokasi Dana Desa di Desa Bongki Lengkese Kecamatan Sinjai Timur Kabupaten Sinjai. Jurnal. Makassar: Universitas Muhammadiyah Makassar.

Romantis, Puteri Ainurrohma. 2015. Akuntabilitas Pengelolaan Alokasi DanaDesa di Kecamatan Panarukan Kabupaten Situbondo Tahun 2014. Skripsi. Jember: Universitas Jember.

Sap, Zulpisardan RajaMuhammad Amin. 2012. Akuntabilitas Pemerintah Desa Dalam Pelaksanaan Alokasi Dana Desa di Desa Bangun Purba Kecamatan Bangun Purba Kabupaten Rokan Hulu. Jurnal. Universitas Riau.

Subroto,Agus. 2009. Akuntabilitas Pengelolaan Alokasi Dana Desa (Studi Kasus Pengelolaan Alokasi dana Desa Di Desa-Desa Dalam Wilayah Kecamatan Tlogomulyo Kabupaten Temanggung Tahun2008). Tesis. Program Studi Magister Sains Akuntansi. Universitas Diponegoro Semarang.

Thomas. 2013. Pengelolaan Alokasi Dana Desa dalam Upaya Meningkatkan Pembangunan di Desa Sebawang Kecamatan Sesayap Kabupaten Tana Tidung. Jurnal Pemerintahan Integratif. FakultasIlmu Sosial danIlmu Politik. Universitas Mulawarman.

Undang-Undang No. 32 tahun 2004 tentang Pemerintahan Daerah.

Undang-Undang Nomor 6 Tahun 2014 tentang Desa. Kementerian Hukum dan Asasi Manusia. 2014.

Wahidah. 2015. Pengaruh Penyajian Laporan Keuangan Daerah dan Aksesibilitas Laporan keuangan Daerah Terhadap Akuntabilitas Pengelolaan Keuangan Daerah Kabupaten Konawe Utara. Skripsi. Fakultas Ekonomi dan Bisnis Universitas Hasanuddin.

Wahyudi, Agus. 2017. Akuntabilitas Pengelolaan Keuangan Desa di Kecamatan Unter Iwes Kabupaten Sumbawa. Skripsi. Mataram: Universitas Mataram.

Wida, Siti Ainul.2016. Akuntabilitas Pengelolan Alokasi Dana Desa di Kecamatan Rogojampi Kabupaten Banyuwangi. Skripsi. Fakultas Ekonomi Universitas Jember.

Widiyanti, Arista. 2017. Akuntabilitas dan Transparansi Pengelolaan Alokasi Dana Desa (Studi Pada Desa Sumberejo dan Desa Kandung di Kecamatan Winongan Kabupaten Pasuruan). Skripsi. Malang: Universitas Islam Negeri (UIN) Maulana Malik Ibrahim Malang.

Wida, Siti Ainul. 2016. Akuntabilitas Pengelolaan Alokasi Dana Desa (ADD) di DesaDesa Kecamatan Rogojampu Kabupaten Banyuwangi. Skripsi. Jember: Universitas Jember.

Zakiyah. 2015. Akuntabilitas Pengelolaaan Keuangan Atas Alokasi Dana DesaTahun 2014 di Desa Pujon Kidul Kecamatan Pujon Kabupaten Malang. Skripsi. Malang: Universitas Islam Negeri (UIN) Maulana Malik Ibrahim Malang. 